Vol. 24, No. 4, pp. 356 367, 2021.

\title{
Progress in Metal-supported Solid Oxide Fuel Cells
}

\author{
Young-Wan $\mathrm{Ju}^{1 \dagger}$ \\ ${ }^{1}$ Departments of Chemical Engineering, College of Engineering, Wonkwang University \\ Iksan, Jeonbuk 54538, Republic of Korea
}

\section{금속지지형 고체산화물 연료전지 연구 동향}

\author{
주용완 $^{1 \dagger}$ \\ 1원광대학교 창의공과대학 화학융합공학과
}

(Received November 30, 2021; Revised December 13, 2021; Accepted December 20, 2021)

\begin{abstract}
s
Solid oxide fuel cells (SOFCs) have been attracting much attention as alternative energy conversion devices due to their high energy conversion efficiency and fuel flexibility. In current SOFCs, Ni-based Cermet anode, solid oxide electrolyte and ceramic cathode have been used. Since all components are ceramic-based materials, there is a problem in that mechanical strength and durability against thermal shock. In order to solve this problem, metal-supported solid oxide fuel cells have designed. Metal-supported solid oxide fuel cells provide significant advantages such as low materials cost, ruggedness, and tolerance to rapid thermal cycling and redox cycling. This paper review the types of metal supports used in metal-based solid oxide fuel cells and the advantages and disadvantages of each metal support.
\end{abstract}

Keywords: Solid Oxide Fuel Cell, Metal support

1. 서론

연료전지는 화학 에너지를 직접 전기 에너지로 고효
율로 변환하는 전기화학 장치이다. Schonbein은 1838 년에 연료전지의 기본 작동 원리를 발견하였다. William Grove는 1839년에 묽은 황산 전해질, 수소-백금 양극

†Corresponding Author: ywju1978@wku.ac.kr 


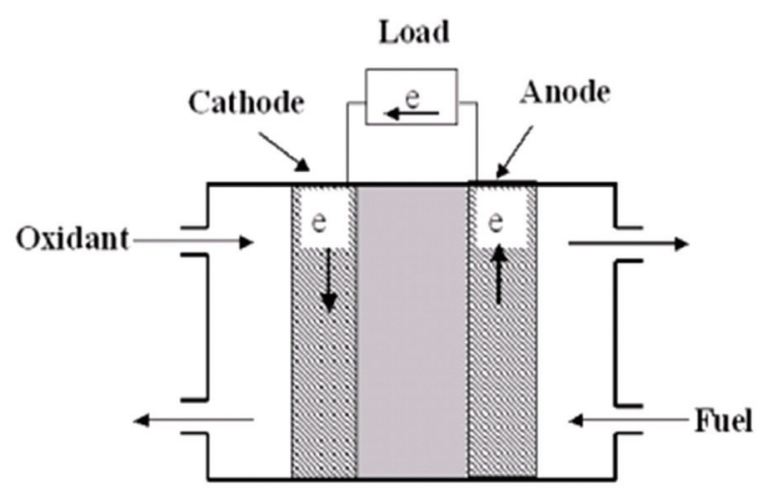

Fig. 1. Schematic of basic fuel cell.

및 산소-백금 음극을 사용하는 최초의 연료 전지를 시 연하였으며, 1952년 Bacon은 알칼리 전해질, 니켈 양극 및 리튬화 니켈 산화물 음극으로 구성된 베이컨 전지로 발명 및 특허를 받았다. 연료 전지는 연료와 산화제의 반응을 통해 전지 내부에서 전기를 생성한다. 연료는 산 화되어 전지의 양극 쪽에서 전자를 생성하고, 생성된 전 자는 외부 회로를 통해 음극으로 흐르고 산화제를 이온 화한다. 이온화된 산화제는 연료와 만나는 양극 쪽으로 이온 확산으로 전해질을 통해 확산하며 연료전지의 기 본 원리는 Fig. 1과 같다.

연료전지는 오랜 역사에도 불구하고 휴대용 및 운송 용으로 신뢰할 수 있는 전기 발전 시스템뿐만 아니라 무 한한 잠재력의 고정식 발전기로 지속 가능한 에너지 자 원으로 여전히 많은 주목을 받고 있습니다. ${ }^{[1]}$ 전해질에 따라 연료전지는 전해질에 따라 고분자전해질연료전 지(PEFC), 인산연료전지 $(\mathrm{PAFC})$, 용융탄산염연료전지
( $\mathrm{MCFC})$, 알칼리연료전지(AFC), 고체산화물 연료전지 (SOFC)로 구분된다. 이들의 특성은 Table 1에 요약되어 있으며, 연료 전지 유형의 가장 큰 차이점은 작동 온도 이다. $\mathrm{MCFC}$ 와 $\mathrm{SOFC}$ 는 모두 $630^{\circ} \mathrm{C}$ 보다 높은 온도에서 작동하는 반면 $\mathrm{AFC}, \mathrm{PAFC}$ 및 $\mathrm{PEMFC}$ 의 작동 온도는 $200^{\circ} \mathrm{C}$ 보다 낮다.

이러한 연료전지 가운데 제 3 세대 연료전지로 분류되 고 있는 고체산화물 연료전지(SOFC)는 일반적으로 산 화물 이온 전도체인 세라믹 전해질을 사용한다. ${ }^{[2,3]}$ 고 체산화물 연료전지는 일반적으로 전해질이 충분히 높은 이온 전도성을 갖는 비교적 높은 온도에서 작동한다. 산 소의 환원에 의해 음극에서 생성된 산화물 이온은 전해 질을 통해 음극에서 양극으로 이동하여 연료와 반응한 다. 동시에 전자는 산화물 이온과 반대 방향으로, 즉 양 극에서 음극으로 이동하여 전기 에너지를 생성하고 반 응의 결과, 탄화수소를 연료로 사용할 때 발생하는 물, 열 및/또는 $\mathrm{CO}_{2}$ 와 같은 소량의 부산물로 전기 에너지가 생성되는데 반응식은 다음과 같다.

$$
\begin{array}{lll}
\text { Cathode }: & \mathrm{O}_{2}+4 \mathrm{e}^{-}=2 \mathrm{O}^{2-} \\
\text { Anode }: & 2 \mathrm{O}^{2-}+2 \mathrm{H}_{2}=2 \mathrm{H}_{2} \mathrm{O}+4 \mathrm{e}^{-} \\
& 2 \mathrm{O}^{2-}+\mathrm{CH}_{4}=2 \mathrm{H}_{2} \mathrm{O}+\mathrm{CO}_{2}+8 \mathrm{e}^{-} \\
\text {Total } & \mathrm{O}_{2}+2 \mathrm{H}_{2}=2 \mathrm{H}_{2} \mathrm{O} \\
& 2 \mathrm{O}_{2}+\mathrm{CH}_{4}=2 \mathrm{H}_{2} \mathrm{O}+\mathrm{CO}_{2}
\end{array}
$$

\begin{tabular}{|c|c|c|c|c|c|}
\hline & $\mathrm{AFC}$ & PAFC & PEMFC & $\mathrm{MCFC}$ & $\mathrm{SOFC}$ \\
\hline Fuel & $\mathrm{H}_{2}$ & $\mathrm{H}_{2}$ & $\mathrm{H}_{2}$ & $\mathrm{H}_{2}$, Hydrocarbon & $\mathrm{H}_{2}$, Hydrocarbon \\
\hline electrolyte & $\mathrm{NaOH}, \mathrm{KOH}$ & $\mathrm{H}_{3} \mathrm{PO}_{4} / \mathrm{SiC}$ & $\begin{array}{l}\text { proton conducting } \\
\text { membrane }\end{array}$ & $\begin{array}{c}\mathrm{Li}_{2} \mathrm{CO}_{3}-\mathrm{K}_{2} \mathrm{CO}_{3} / \\
\mathrm{LiAlO}_{2}\end{array}$ & $\begin{array}{l}\text { oxygen ion conduc- } \\
\text { tor }\end{array}$ \\
\hline charge species & $\mathrm{OH}^{-}$ & $\mathrm{H}^{+}$ & $\mathrm{H}^{+}$ & $\mathrm{CO}_{3}{ }^{2-}$ & $\mathrm{O}^{2-}$ \\
\hline $\begin{array}{l}\text { operation tem- } \\
\text { perature }\end{array}$ & $323 \sim 473 \mathrm{~K}$ & $433 \sim 483 \mathrm{~K}$ & $\begin{array}{c}\text { Room } \\
\text { temperature } 373 \mathrm{~K}\end{array}$ & 903 923K & $673 \sim 1273 \mathrm{~K}$ \\
\hline Electrode & Metal or carbon & Pt on carbon & Pt on carbon & $\begin{array}{l}\mathrm{Ni}(\text { anode / } \mathrm{NiO} \\
\quad \text { (cathode) }\end{array}$ & $\begin{array}{c}\text { Ni-based } \\
\text { Cermet(anode)/ } \\
\text { Ceramic(cathode) }\end{array}$ \\
\hline
\end{tabular}

고체산화물 연료전지는 연료 유연성, 높은 에너지 변 환 효율 및 간단한 내부 개질 시스템으로 인해 차세대

Table 1.1. Categories and characteristic of fuel cells. 


\section{Electrolyte-supported cell}

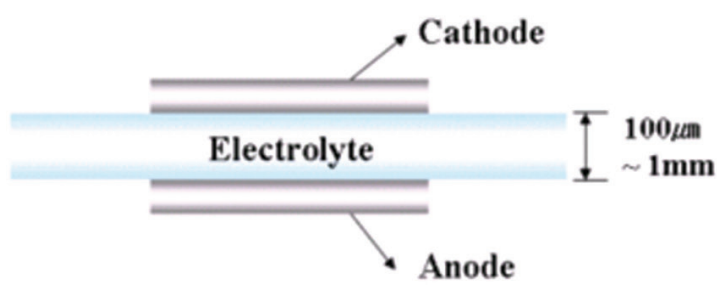

\section{Electrode-supported cell}

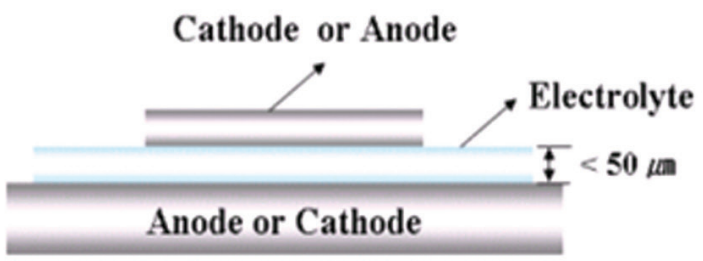

Fig.. 2. Schematics of electrolyte-supported cell and electrode-supported cell.

유망 발전기로 간주된다. ${ }^{[4]}$ 내부 개질을 허용하는 높은 작동 온도의 장점은 빠른 전기 촉매 반응을 촉진한다는 것이다. 이러한 내부 개질 시스템을 사용하여 시스템이 단순해지고 비용이 절감된다. 또한 전극으로 비귀금속 물질이 사용되어 열과 전기에너지의 복합에너지 발전시 스템이 가능하며, 이에 따라 최대 $70 \%$ 에 달하는 고체산 화물 연료전지의 효율은 열 병합 방식으로 $20 \%$ 의 추가 효율을 얻을 수 있다. 또한, 고온의 배기열 때문에 보텀 사이클(Bottoming cycle), 즉 가스 또는 증기 터빈 시스 템과의 조합도 고려되며 연료에서 전기 에너지로의 매 우 높은 에너지 변환 효율을 달성할 수 있다.

현재 고체산화물 연료전지에 관한 연구는 전해질 층 을 얇은 양극 및 음극층에 대한 기계적 지지체로 사용하 는 전해질 지지 전지를 사용하여 주로 개발되고 있다. 이 유형의 셀은 높은 작동 온도에서 안정적인 전력을 얻 을 수 있지만 작동 온도를 낮추면 성능이 크게 저하됩니 다. 이것은 두꺼운 전해질의 높은 내부 저항과 관련이 있다. 따라서 이러한 유형의 전해질 지지형 전지는 일반 적으로 $800 \sim 1000^{\circ} \mathrm{C}$ 의 온도에서 작동한다. 그러나 이러 한 높은 작동 온도는 상당한 단열 및 값비싼 고온 재료 가 필요하다. 또한, $\mathrm{Ni}$ 계 음극에서는 $\mathrm{Ni}$ 응집이 발생한 다는 문제점을 가지고 있다. 따라서 현재 전해액의 두께 를 줄여 전해액의 내부 저항을 줄이기 위한 전극 지지체 가 사용하려는 연구가 진행되었다. 전극 지지 전해질막 의 두께는 일반적으로 $50 \mu \mathrm{m}$ (Fig. 2)보다 얇으며 전지 는 $800^{\circ} \mathrm{C}$ 이하에서 작동하므로 전극 지지형 전지는 전 해질 저항이 작아 전해질 지지 전지보다 높은 발전 특성 을 보여주었다. 하지만, 전극 지지형 및 전해질 지지형
고체산화물 연료전지 모두 세라믹 재료 또는 Cermet을 지지체로 사용하고 있기 때문에, 세라믹 또는 Cermet의 낮은 기계적 강도와 열팽창 특성으로 인해 고체산화물 연료전지의 다양한 활용을 제한한다. 본 논문에서는 고 체산화물 연료전지에 사용되고 있는 구성 요소들의 특 징을 살펴보고, 고체산화물 연료전지의 문제 해결을 위 하여 금속 지지체를 사용하여 개발되고 있는 금속 기반 형 고체산화물 연료전지에 대하여 살펴보고자 한다.

\section{2. 본론}

\section{1 고체산화물 연료전지}

고체산화물 연료전지는 높은 작동 온도로 인하여 전 해질, 양극 및 음극으로 사용되는 재료에 대하여 다양한 특성이 요구된다. 현재 고체산화물 연료전지 시스템에서 모든 구성 요소는 세라믹 또는 세라믹 기반 Cermet으로 구성되며 모든 구성 요소는 해당 화학 환경에서 화학적 및 물리적 안정성, 다른 구성 요소와의 화학적 호환성, 적절한 전도도 및 다른 구성 요소와 유사한 열팽창 계수 와 같은 기능을 가져야 한다. 고체산화물 연료전지에 사 용되는 구성 요소들의 구체적 특징은 다음과 같다.

전해질 : 전해질의 주요 기능은 산화물 이온을 전도하 는 것입니다. 음극에서 생성된 산화물 이온은 낮은 산소 분압 영역(음극)으로 이동한다. 옴 내부 저항은 연료전 지 성능을 지배하는 주요 요인 중 하나이며 전해질에 대 한 주요 요구 사항은 다음과 같다.

(1) 안정성 : 전해질은 이중 분위기, 즉 $\mathrm{H}_{2}$ 와 $\mathrm{O}_{2}$ 에서 화학적, 형태학적으로 안정해야 한다. 
(2) 전도도 : 전해질은 적절한 이온 전도도를 가져야 한다. 옴 손실을 최소화하려면 이온 전도도가 최 대한 높아야 한다. 전해질은 또한 전압 손실을 방 지하기 위해 무시할 수 있을 만큼 낮은 전자 전도 도를 가져야 한다.

(3) 호환성 : 전해질은 작동 과정뿐만 아니라 제조할 때도 다른 전지 구성 요소와 화학적으로 호환성이 있어야 한다.

(4) 열 팽창 : 전해질의 열 팽창은 열 순환을 포함하여 제조 및 작동 중 균열 및 박리를 피하려고 다른 전 지 구성 요소의 열 팽창 특성과 유사해야 한다.

(5) 다공성 : 전해질은 반응물의 교차를 방지하고 전 도도를 최대화하기 위해 조밀해야 한다.

Fig. 3는 다양한 고체산화물 연료전지 전해질의 온도 에 따른 산소 이온 전도도를 나타낸 그래프이다. 기존 고체산화물 연료전지의 전해질로 가장 일반적으로 사용 되고 있는 것은 이트리아 $\left(\mathrm{Y}_{2} \mathrm{O}_{3}\right)$ 와 같은 이종 원소로 안 정화 지르코니아 $\left(\mathrm{ZrO}_{2}\right)$ 이다. ${ }^{[5-9]}$ 순수한 $\mathrm{ZrO}_{2}$ 는 실온에 서 단사정계이지만, $1150^{\circ} \mathrm{C}$ 이상의 온도에서는 정방정 계 구조로 상전이를 나타냅니다. 이트리아는 $\mathrm{ZrO}_{2}$ 에 높 은 용해도를 나타내며 이트리아로 안정화된 지르코니아 는 상온에서 융점 $\left(2650^{\circ} \mathrm{C}\right)$ 까지 입방형 형석 구조를 유 지한다. $\mathrm{ZrO}_{2}$ 의 결정 배열은 모든 지르코늄 이온에 대 해 2개의 산화물 이온을 가지고 있으나 $\mathrm{Y}_{2} \mathrm{O}_{3}$ 에는 모든 이트륨 이온에 대해 1.5 개의 산화물 이온만 있다. 따라 서 안정화에 의해 산화물 이온 결손의 농도를 증가시켜 이온 전도도를 증가시켰다. YSZ는 전자 전도 특성이 없 는 순수한 산소 이온 전도성을 가지며, 산화 및 환원 분 위기 모두에서 우수한 안정할 뿐 아니라 고체산화물 연 료전지에 사용되는 다른 구성 요소와의 반응성이 없다.

최근에는 고체산화물 연료전지의 작동 온도를 낮추 기 위하여, 낮은 온도에서 우수한 산소 전도 특성을 보 여주는 다양한 물질을 전해질로 사용하는 시도가 도입 되고 있다. $\mathrm{Gd}$ 도핑된 $\mathrm{CeO}_{2}(\mathrm{GDC})$ 와 같은 $\mathrm{Ce}$ 기반 산 화물 이온 전도체는 낮은 온도에서 높은 이온 전도성을 나타내지만 불행하게도 세리아는 부분적으로 $\mathrm{Ce}^{3+}$ 로 환 원되어 도핑된 세리아를 혼합 전도체로 만든다. 따라서

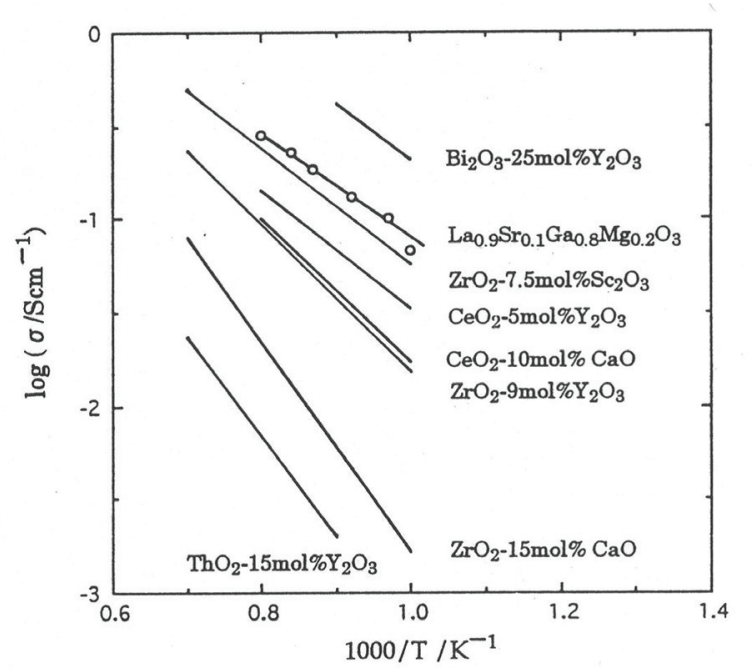

Fig. 3. Comparison in oxygen ion conductivity of various type of solid oxide electrolyte as a function of temperature. Adapted from Ishihara et al. J. Am. Chem. Soc., 1994;116:3801-3, with permission of American Chemical Society [5].

OCV(Open Circuit Voltage)가 감소하고 전력을 생산 하지 않는 연료 소비도 시스템 효율을 저하한다. 또 다 른 전해질로 주목받는 물질은 페로브스카이트 산화물인 란탄 갈레이트 $\left(\mathrm{LaGaO}_{3}\right)$ 이다. ${ }^{[10,11]}$ 란탄 갈레이트는 저온 작동 고체산화물 연료전지의 대체 전해질로 많은 관심 을 받고 있으며, 도핑된 $\mathrm{LaGaO}_{3}$ 에서 가장 선호되는 조 성은 $\mathrm{La}_{0.9} \mathrm{Sr}_{0.1} \mathrm{Ga}_{0.8} \mathrm{Mg}_{0.2} \mathrm{O}_{2.85}$ (LSGM)이다. LSGM의 이 온 전도도는 중간 온도 $\left(700 \sim 300^{\circ} \mathrm{C}\right)$ 에서 $\mathrm{YSZ}$ 보다 훨씬 높다. 그러나 LSGM은 다른 구성 요소와의 반응성과 같 은 몇 가지 단점이 있으며 반응의 결과, 전도성이 낮은 $\mathrm{La}_{4} \mathrm{Ga}_{2} \mathrm{O}_{9}$ 및 $\mathrm{SrLaGa}_{3} \mathrm{O}_{7}$ 과 같은 일부 2차 상이 발생한 다. 비스무트 산화물은 또한 높은 산화물 이온 전도성으 로 인해 새로운 전해질의 후보로 간주된다. 그러나 낮은 산소 분압과 높은 반응성에서 물질의 분해로 인해 전해 질로의 더 넓은 적용은 방지되는데 이런 문제를 극복하 기 위해 도핑된 세리아 전해질을 사용한 이중층 전해질 구조도 보고되었다. 이중층 전해질을 제조함으로써 비 스무트 산화물의 낮은 산소 분압에서의 분해를 방지할 수 있고 전기적 도핑된 세리아의 환원 분위기에서 전도 도를 해결할 수 있다. 
양극 : 양극에서의 주요 반응은 산화제의 환원으로, 분자 산소의 환원, 전하를 띤 화학종을 전해질로 이동, 산소 환원 반응과 관련된 전류 분포로 구성된다. 고체산 화물 연료전지의 양극에 대한 주요 요구 사항은 아래에 설명되어 있다.

(1) 높은 전자 전도성 $>100 \mathrm{~S} / \mathrm{cm}$ )

(2) 산소 이온 전도도

(3) 산소 분자 흡착 및 해리, 산소 환원을 위한 높은 촉매 활성

(4) 다른 셀 구성 요소와 열팽창 계수의 일치

(5) 반응 부위로 기체를 운반할 수 있는 충분한 다공성 높은 작동 온도에서 양극 반응은 매우 빠르게 발생하 는데, 기존 고체산화물 연료전지 시스템에서는 $(\mathrm{La}, \mathrm{Sr})$ $\mathrm{MnO}_{3}(\mathrm{LSM})$ 가 양극 재료로 사용되고 있다. LSM은 높 은 작동 온도에서 YSZ 전해질을 사용하는 고체산화물 연료전지에서 우수한 양극 특성을 보이지만, YSZ과의 반응에 의하여 $\mathrm{La}_{2} \mathrm{Zr}_{2} \mathrm{O}_{7}$ 절연상이 2차상으로 형성된다 는 문제점을 가지고 있다. ${ }^{[12]}$ 또한, 고체산화물 연료전 지의 작동 온도를 낮추면 산소 환원 반응의 비가역성 및 전하 이동 단계에 기인한 분극 손실이 증가하여 산소 이 온 전도도가 감소한다. 따라서, 중저온에서 촉매 특성이 높은 대체 양극의 개발이 많은 관심을 받고 있으며, 최 근 MIEC (혼합이온전기전도체)가 유망한 양극재로 많 은 관심을 받고 있다. $(\mathrm{LnSr}) \mathrm{CoO}_{3-\delta}(\mathrm{Ln}: \mathrm{La}, \mathrm{Pr}, \mathrm{Sm}$, $\mathrm{Gd}),(\mathrm{LaSr})(\mathrm{CoFe}) \mathrm{O}_{3-\delta},(\mathrm{BaSr})(\mathrm{CoFe}) \mathrm{O}_{3-\delta}$ 등의 페로브 스카이트계 재료가 높은 활성 때문에 양극 물질의 훌륭 한 대안으로 간주된다. ${ }^{[13,14]}$

음극 : 고체산화물 연료전지에서 음극의 주요 반응은 연료의 전기화학적 산화이다. 음극 물질은 환원 분위기 에서 안정해야 하고 작동 조건에서 연료 가스 반응을 위 한 충분한 전자 전도성과 촉매 활성을 가져야 한다. 따 라서 다양한 금속 촉매가 음극 물질로 고려됐는데, $\mathrm{Mn}$, $\mathrm{Fe}, \mathrm{Co}, \mathrm{Ni}, \mathrm{Ru}, \mathrm{Pt}$ 의 전기화학적 활성을 비교하면 $\mathrm{Ni}$ 이 $\mathrm{H}_{2}$ 환원에 대한 활성이 가장 높은 것으로 확인되었 다. ${ }^{[15,16]}$ 음극 재료는 높은 전기화학적 활성과 다음과 같 은 특성을 모두 가져야 한다.

(1) 작동 온도에서 환원 환경에서 충분히 높은 전자 전
도도 $>100 \mathrm{~S} / \mathrm{cm})$

(2) 산소 이온 전도도(혼합 전도도 향상)

(3) 수소 분자 또는 연료 흡착 및 해리, 연료의 전기 화학적 산화에 대한 높은 촉매 활성

(4) 다른 셀 구성 요소와 열팽창 계수의 일치

(5) 가스가 반응 부위로 이동할 수 있도록 충분한 다 공성

그러나 순수 $\mathrm{Ni}$ 음극은 전해질보다 열팽창계수가 크 고 산화성 분위기에서 불안정하다는 몇 가지 단점이 있 다. 또한, $1350^{\circ} \mathrm{C}$ 보다 높은 온도에서 $\mathrm{Ni}$ 는 LSGM과 반 응하여 일부 절연 구조 $\left(\mathrm{LaSrGa}(\mathrm{Ni}) \mathrm{O}_{4}\right.$ 및 $\left.\mathrm{LaNiO}_{4}\right)$ 를 형 성한다. 따라서 일반적으로 $\mathrm{NiO}$ 와 이온 전도체를 혼합 한 Cermet이 음극 재료로 사용되는데, 이러한 Cermet 음극은 촉매 활성과 안정성이 우수하다. Cermet 음극을 사용하여 열팽창의 불일치가 감소하고 3상 경계(TPB) 가 확장된다. 습한 수소 또는 연료 분위기에서 $\mathrm{NiO}$ 의 환원은 기공 표면에 금속성 니켈 입자가 있는 다공성 Cermet 구조를 생성된다. 환원 후, Cermet 음극은 잘 발달된 고체 산화물 전해질 골격과 내부 다공성 공간으 로 구성되며, 이 구성은 촉매 반응을 위해 긴 $\mathrm{TPB}$ 를 도 입하고 $\mathrm{TPB}$ 에서 집전체로 전자 전도를 제공한다. ${ }^{[17,18]}$ 따라서 $\mathrm{Ni}$ 기반 Cermet 음극은 일반적으로 고체산화 물 연료전지에 사용되었으며 충족된 음극 요구 사항 대 부분을 달성할 수 있다. 그러나 Cermet 음극의 $\mathrm{Ni}$ 입 자는 높은 작동 온도에서 소결 현상이 발생하는 문제점 을 가지고 있다. 이러한 고체산화물 연료전지에서 발생 하는 문제점들은 대부분 높은 작동 온도에서 기인하고 있으며, 많은 연구자가 고체산화물 연료전지의 작동 온 도를 낮추고 높은 에너지 변환 효율과 출력 밀도를 얻을 수 있는지 연구를 진행하고 있다. 고체산화물 연료전지 의 작동 온도를 낮추는 방법 가운데 하나는 전해질의 두 께를 낮추는 것이다.

\section{2 금속 기반형 고체산화물 연료전지}

금속 기반형 고체산화물 연료전지는 강력한 기계적 강도, 빠른 시동, 우수한 산화환원 내성, 균일한 온도 및 높은 열 순환 내성으로 인해 최근 많은 관심을 받고 있 
다. 1969년에 Williams와 Smith는 처음으로 금속 기반 고체산화물 연료전지의 개념을 보고했습니다. ${ }^{[19]}$ 그들은 화염 스프레이를 사용하여 사전 소결된 오스테나이트계 스테인리스강 지지체 위에 지르코니아 기반 전해질을 제작했다. 금속 지지 고체 산화물 연료전지는 $\mathrm{Ni}, \mathrm{NiFe}$, $\mathrm{NiCrAlY}$ 및 페라이트계 스테인리스강을 포함한 다양한 금속 조성을 가진 지지체 위에 준비된다. 금속 기반형 고체산화물 연료전지에서 빠른 열 순환을 가능하게 하 려면 금속 지지체의 열 팽창계수(Thermal Expansion Coefficient, TEC)를 전해질의 계수와 일치시키는 것이 바람직하다. 많은 연구자가 다양한 금속 기반을 이용하 여 금속 기반형 고체산화물 연료전지에 대한 실험을 진 행하였으며 금속 기반의 종류에 따라 분류하여 자세히 살펴보고자 한다.

\subsubsection{Ni 기반 물질}

초기 연구에서는 다이 프레스를 통해 준비된 다공성 $\mathrm{NiCrAlY}$ 금속 지지체에 플라즈마 분무를 이용하여 두 꺼운 이트리아 안정화 지르코니아(YSZ) 전해질을 사용 했다. ${ }^{[20]} \mathrm{NiCrAlY}$ 합금의 우수한 내산화성은 $900{ }^{\circ} \mathrm{C}$ 까지 작동이 가능하여 두꺼운 전해질에도 불구하고 합리적인 성능을 얻을 수 있다.

반면 최근 여러 그룹에서 다공성 순수 $\mathrm{Ni}$ 를 지지체 재료로 사용했다. $\mathrm{Ni}$ 의 높은 비용, 전해질에 대한 열 악한 TEC 일치, 낮은 산화환원 내성, 코킹 및 황 손상 에 대한 민감성은 이 지지체 재료의 활용을 억제하는 중 요한 문제점으로 고려되고 있다. 그러나 Ogumi 교수 의 연구팀은 다공성 순수 $\mathrm{Ni}$ 튜브를 이용하여 마이크 로 연료 전지를 제작하였다 ${ }^{[21]}$. $\mathrm{NiO}$ 의 산화-환원 과정 을 이용하여 $0.5 \sim 2.5 \mu \mathrm{m}$ 범위의 기공을 가진 $1 \mathrm{~mm}$ 직경의 $\mathrm{Ni}$ 튜브를 준비하였으며, 제조된 $\mathrm{Ni}$ 튜브 기 판에 YSZ를 전기화학증착법(electrochemical vapor deposition, EVD)으로 직접 증착하였다. 따라서 $\mathrm{Ni}$ 튜 브는 지지체이자 음극 역할을 수행한다. 앞서 언급한 것 과 같이 $\mathrm{Ni}$ 의 $\mathrm{TEC}$ 는 $\mathrm{YSZ}$ 의 $\mathrm{TEC}$ 보다 상당히 높아 단 위 전지 제조 과정 및 연료전지 운전 과정에서 균열이 발생할 수 있다. 그러나 직경이 작은 마이크로 튜브 형
태와 $\mathrm{EVD}$ 의 비교적 낮은 증착 온도 $\left(1000^{\circ} \mathrm{C}\right)$ 에서 $\mathrm{YSZ}$ 증착을 진행하여 열 응력이 완화되어 균열 발생을 억 제하였다. 또 다른 연구 그룹인 Hwang 교수 연구팀 은 다공성 $\mathrm{Ni}$ 을 지지체로 사용하여 대기압 플라즈마 스 프레이(atmospheric plasma spraying, APS) 증착으 로 Ni-YSZ / LSGM $\left(\mathrm{La}_{0.8} \mathrm{Sr}_{0.2} \mathrm{Ga}_{0.8} \mathrm{Mg}_{0.2} \mathrm{O}_{3}\right)$ / LSCF $\left(\mathrm{La}_{0.58} \mathrm{Sr}_{0.4} \mathrm{Co}_{0.2} \mathrm{Fe}_{0.8} \mathrm{O}_{3}\right)$ 층을 제조하였다. ${ }^{[22]}$ 플라즈마 스프레이를 통해 제조된 각 기능성 음극, 전해질 그리 고 양극층은 $1000^{\circ} \mathrm{C}$ 에서 소결하였는데, $1000^{\circ} \mathrm{C}$ 의 온도 는 LSGM과 $\mathrm{Ni}$ 사이의 반응에 의한 불순물 성장을 피할 수 있는 낮은 온도이면서, LSGM 전해질 층이 반응 가 스들의 흐름을 억제할 만큼 충분히 밀도가 높게 성장할 수 있는 온도이다. 이러한 과정으로 제조된 단위전지는 $800^{\circ} \mathrm{C}$ 에서 $440 \mathrm{~mW} \cdot \mathrm{cm}^{-2}$ 의 우수한 전력밀도를 보여 주었다. 이와 유사한 연구를 Choi 교수 연구팀에서도 진 행하였는데, 제조된 $\mathrm{Ni}$ 지지체/Ni-YSZ 음극/YSZ 전 해질의 삼중층 구조를 $1400^{\circ} \mathrm{C}$ 에서 동시 소결하여 단위 전지를 제조하였다. ${ }^{[23]}$ 높은 소결온도로 인하여 음극 내 $\mathrm{Ni}$ 의 결정 성장이 소결 동안 발생하였음에도 불구하고 $800^{\circ} \mathrm{C}$ 에서 $470 \mathrm{~mW} \cdot \mathrm{cm}^{-2}$ 의 우수한 전력 밀도가 달성 되었다.

순수한 $\mathrm{Ni}$ 을 금속 지지체로 사용하여 제조하는 연구 에서 여러 연구 그룹들이 의미 있는 결과를 얻었으나, 소결 및 단위전지 측정 과정에서 $\mathrm{Ni}$ 입자가 성장하는 문 제점이 관찰되었다. 이러한 문제를 해결하고 낮은 온도 에서 음극의 촉매 활성을 증가시키기 위하여 $\mathrm{Ni}$ 음극 지 지체에 소량의 금속을 도핑하여 합금을 제조하고 이를 금속 지지체로 사용하는 연구가 진행되었다. ${ }^{[24]}$ Fig. 4 는 다양한 금속을 이용하여 제조된 $\mathrm{Ni}$ 기반 합금의 과 전압을 나타낸 그림이다. 소량의 $\mathrm{Fe}$ 을 첨가하여 제조한 $\mathrm{Ni}-\mathrm{Fe}$ 합금은 순수한 $\mathrm{Ni}$ 및 다른 금속 첨가 $\mathrm{Ni}$ 보다 높 은 촉매 활성을 보여주었다. 또한 소량의 이종 금속 첨 가는 $\mathrm{Ni}$ 응집을 방지하고 $\mathrm{Ni}$ 에 대한 미세 구조를 최적화 하는데 이바지하였다. 그래서 소량의 철을 이용해 제조 된 $\mathrm{Ni}$ 합금을 기반으로 $\mathrm{LSGM} / \mathrm{SDC}{ }^{[24-27]}$ 및 $\mathrm{GDC}{ }^{[28,29]}$ 전해질을 사용하는 금속 기반형 고체산화물 연료전지를 제조한 연구들이 진행되었다. $\mathrm{Fe}$ 의 추가는 순수한 $\mathrm{Ni}$ 에 


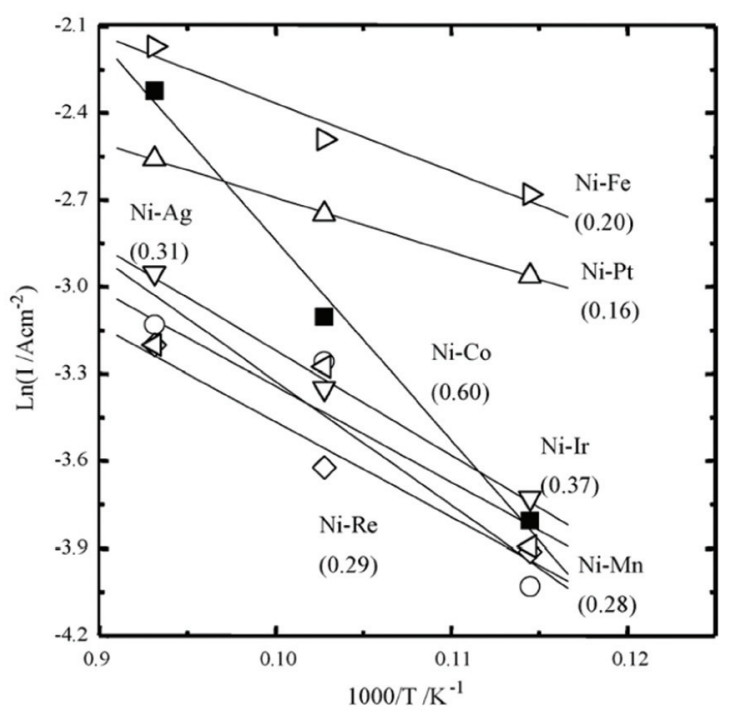

Fig. 4. Arrhenius plots of the current density at the anodic overpotential of $30 \mathrm{mV}$ on various $\mathrm{Ni}$ based bimetallic anode. Values in figure is estimated activation energy (eV). Adapted from Ishihara et al. Electrochim. Acta, 2006:52:1645-50, with permission of Elsevier [27].

비교하여 저렴하며 열 팽창계수 차이도 완화시킬 수 있 다는 장점이 있다. 이러한 $\mathrm{Ni}-\mathrm{Fe}$ 합금은 비교적 간단하 게 제조할 수 있다. Fig. 5과 같이 금속 지지체는 $\mathrm{NiO}$ 와 질산철을 이용한 함침법으로 준비되었다. 함침법으 로 제조된 금속산화물 복합체를 이용하여 조밀도가 높 은 디스크를 프레스를 통해 제조하된 금속산화물 지지 체는 소결 후 높은 밀도를 보여주었다. 따라서 얇은 전 해질 막 제조가 용이하다는 장점을 가지고 있다. 제조된 금속산화물 지지체는 고체산화물 연료전지 성능 평가 과정에서 공급되는 연료의 흐름에 의하여 환원되며 $\mathrm{NiO}$ 와 $\mathrm{Fe}_{3} \mathrm{O}_{4}$ 의 환원 속도 차이에 의하여 나노 크기의 기공 이 형성되어 충분한 다공성을 제공하게 됩니다. 또한 10 $\mathrm{wt} . \%$ 의 철이 첨가된 $\mathrm{Ni}$ 기반 금속산화물을 $700^{\circ} \mathrm{C}$ 이상 의 온도에서 환원 처리하면 LSGM과 유사한 TEC를 보 여 $\mathrm{Ni}-\mathrm{Fe}$ 합금 위에 제조된 LSGM 전해질 필름의 박리 가 억제될 수 있다. 또한 이러한 합금 기반 위에 펄스 레 이저 증착을 통해 $6 \mu \mathrm{m}$ 의 LSGM 전해질을 코팅하여 제 조한 금속기반형 고체산화물 연료전지는 $700^{\circ} \mathrm{C}$ 에서 약 $1.8 \mathrm{~W} \cdot \mathrm{cm}^{-2}$ 의 높은 성능을 보여주었다. ${ }^{[25]} \mathrm{Zhu}$ 교수의

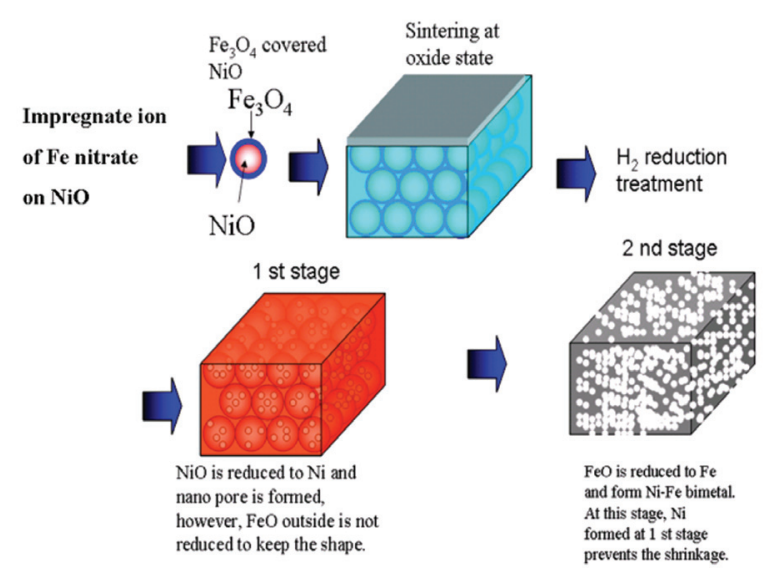

Fig. 5. Concept for fabricating porous metal substrate.

연구 그룹은 $\mathrm{Ni}$ 에 $\mathrm{Fe}$ 첨가에 따른 $\mathrm{TEC}$ 변화를 연구하 였는데, $\mathrm{Fe}$ 의 첨가량이 증가하면 YSZ 전해질의 TEC와 유사하게 증가하여 중량비가 1:1에 가까운 합금이 YSZ 에 가장 잘 맞는 $\mathrm{TEC}$ 를 갖는 것으로 밝혀졌다. ${ }^{[30]}$ 이렇 게 $\mathrm{Ni}$ 합금에 존재하는 $\mathrm{Fe}$ 의 무게비가 증가하면 금속 기 반의 비용이 절감되어 전체 고체산화물 연료전지 제작 비용이 감소한다는 장점을 가지고 있다. 그래서 Choi 교 수 그룹은 중량비 $1: 1$ 의 $\mathrm{Ni}-\mathrm{Fe}$ 합금 $20 \mu \mathrm{m}$ 에 $2 \mu \mathrm{m}$ 두께 의 가둘리늄 도핑 세리아 (Gadolinium-doped ceria, $\mathrm{GDC}$ ) 전해질을 코팅한 마이크로 고체산화물 연료전지 를 제작하였다 ${ }^{[28]}$.

\subsubsection{Fe 기반 물질}

많은 개발자는 금속 지지대에 페라이트계 스테인리스 강을 선호한다. 페라이트계 스테인리스강은 탄소 함량 이 매우 낮은 철과 크롬을 주로 함유하는 체심 입방체, 강자성 합금이며, 일반적인 합금 명칭에는 430,409 , 410 및 441이 포함된다. 이러한 합금은 저렴한 가격 및 고온 내산화성 때문에 자동차 배기 매니폴드 및 머플러 에 널리 사용된다. 페라이트계 스테인리스강은 일반적 으로 연속 크로미아 산화막을 형성하기 위해 $10.5 \mathrm{wt} . \%$ 이상의 $\mathrm{Cr}$ 을 함유하고, 더 높은 $\mathrm{Cr}$ 함량에서 취성 시그 마 상의 형성을 피하기 위해 $26 \mathrm{wt} . \%$ 이하의 $\mathrm{Cr}$ 이 함유 된다. 합금에는 강도, 열팽창성, 내열 및 내식성등의 물 
성을 향상시키기 위해 종종 $\mathrm{Ni}, \mathrm{Mo}, \mathrm{Si}, \mathrm{Ti}, \mathrm{Al}$ 등이 포 함된다. 이러한 페라이트계 스테인리스강을 고체산화 물 연료전지에 사용할 경우 매우 저렴하고, 얇고 연속적 인 전도성 크로미아 스케일을 생성하며 고체산화물 연 료전지 작동 온도에서 매우 긴 수명을 가질 수 있다는 장점을 가지고 있다. 또한 $\mathrm{TEC}$ 도 전해질 재료인 YSZ 및 $\mathrm{CGO}$ 와 유사하여 전해질막의 박리를 억제할 수 있 다는 장점도 가지고 있다. 또한 $\mathrm{Al}$ 을 첨가하면 강 표면 에 $\mathrm{Al}_{2} \mathrm{O}_{3}$ 산화층을 형성하여 스테인리스강의 내산화성 을 향상시킬 수 있고, $\mathrm{Si}$ 를 첨가하면 산화층과 스테인리 스강 사이에 $\mathrm{SiO}_{2}$ 산화층을 형성하여 접착력을 향상시 킬 수 있다는 것은 널리 알려져 있다. 그러나 스테인리 스강에서 형성된 크롬산화물의 상대적으로 높은 전도도 는 지지체/전극 인터페이스에서 허용 가능한 접촉 저항 을 유지하는 데 매우 중요하다. 따라서 $\mathrm{Al}$ 또는 $\mathrm{Si}$ 의 추 가는 불행히도 그들이 형성하는 산화층이 비전도성인 관계로 고체산화물 연료전지의 전기적 특성에 부정적인 영향을 주게 된다. 마찬가지로 300 시리즈 스테인리스 강은 고체산화물 연료전지의 작동 온도 범위에서 비전 도성 혼합 $\mathrm{Fe}-\mathrm{Cr}-$ 산화물 스케일을 빠르게 형성하고 훨 씬 더 높은 $\mathrm{TEC}$ 를 갖는다 ${ }^{[31]}$. 이러한 이유로 페라이트계 스테인리스강은 금속 기반형 고체산화물 연료전지의 금 속 지지체로 선택된다.

페라이트계 스테인리스강 지지체는 레이저 드릴링을 통해 제조된 천공 시트 ${ }^{[32-34]}$ 와 테이프 주조 ${ }^{[35]}$ 및 등방압 압축 ${ }^{[36,37]}$ 을 포함한 표준 분말 야금 방법으로 제조된다. 고다공성 스테인리스 스틸 부품도 압출 및 분말 소결에 의해 일상적으로 제조되며 이러한 방법은 대량 제조에 이점이 있다고 알려져 있다. 미리 형성된 시트를 레이 저 드릴링하면 전기화학적 활성층을 증착할 수 있는 매 끄럽고 잘 정의된 표면이 제공된다. 충분히 높은 밀도의 10-30 $\mu \mathrm{m}$ 홀의 도입은 기체 확산 모델링에 의해 지지 체를 통해 활성층으로 반응물의 적절한 확산을 지원하 기에 충분하다는 것을 발견했다 ${ }^{[38]}$. 레이저 드릴링으로 제조된 스테인리스강 지지체 시트는 음극 및 전해질 등 의 전기화학 층의 제조 과정 중에 수축되지 않는다. 이 것은 전체 밀도로 제한 소결될 수 있는 CGO 또는 YSZ
의 플라즈마 스프레이 증착에 대해 허용되지만 YSZ 전 해질의 동시 소결을 배제한다. 분말 야금법을 통해 제조 된 스테인리스강 지지체의 경우에도 마찬가지이다. 고 체산화물 연료전지 구성 요소를 제조하는 과정 중에 수 축되지 않는 예비 소결된 지지체는 $\mathrm{CGO}^{[34,39,40]}$ 및 용융 분사법으로 제조된 $\mathrm{YSZ}^{[41]}$ 와 함께 사용되는 반면 지지 체와 전해질 층의 동시 소결은 습식 또는 콜로이드 YSZ 증착 공정에 사용해야 한다. ${ }^{[36,37]}$ 분말 야금 지지체가 전 해질과 함께 예비 소결되거나 동시 소결 여부와 관계없 이 적절한 가스 수송을 제공하기 위해 고체산화물 연료 전지 구성 요소 제조 후에 충분한 다공성을 유지해야 한 다. 원하는 다공성을 달성하기 위한 적절한 단계를 수행 해야 하며, 그렇지 않으면 조밀한 지지 구조가 농도 분 극으로 인해 심각한 제한 전류 밀도를 부과할 수 있다.

최종 지지체 다공성은 소결 온도, 입자 크기, 입자 크 기 분포, 합금 조성, 입자 형태, 기공 형성제, 결합제 및 다른 층의 수축률에 따라 달라진다. 이러한 복잡한 상호 관계를 탐색하기 위한 몇 가지 지침은 Kurokawa 교수 연구팀은 4101 스테인레스 스틸 분말을 수성 아크릴 바 인더 및 $\mathrm{PEG}$ 기공 형성제와 혼합하였다. ${ }^{[42]}$ 물 분무 분 말은 기체 분무 분말보다 횔씬 거친 형태를 갖기 때문 에 선택되었다. 이것은 더 낮은 패킹 밀도와 더 높은 초 기 다공성을 초래한다. 거친 입자 사이의 기계적 인터로 킹은 또한 녹색 및 탈결합 상태에서 핸들링 강도를 향상 시킨다. 금속 입자 크기 및 기공 형성제/결합제 함량의 함수로서 최종 밀도 및 수축의 상세한 지도가 제시되었 다. 금속 입자가 작을수록 수축률이 높아져 YSZ 수축률 과 일치하지만, 최종 기공률이 낮아진다. 결합제 및 기 공 형성제 함량을 증가시켜 다공성을 개선할 수 있지만, 지지체 전체의 부피 수축이 발생한다. 따라서 주어진 금 속 분말에 대해 최적의 바인더/기공 형성제 함량을 결정 해야 한다.

Table 2와 같이 다양한 금속 지지체 구성과 구조가 고 체산화물 연료전지에 적용되었다. 페라이트계 스테인리 스강은 저비용, 일반 전해질 재료와 일치하는 TEC, 전 도성 보호 스케일 형성 및 적절하게 낮은 산화율 때문에 선호되는 재료이다. 그러나 페라이트계 스테인리스강 
Table 2. Thermal Expansion coefficient(TEC) of metal and electrolyte in SOFC.

\begin{tabular}{c|c|c|c}
\hline Materials & TEC $\left(\mathrm{ppm} \cdot \mathrm{K}^{-1}\right)$ & Cost $(\$ / \mathrm{kg})$ & Relative oxidation resistance \\
\hline NiCrAlY alloy & $15 \sim 16$ & 63 & Excellent \\
\hline $\mathrm{Ni}$ & 16.5 & 18 & - \\
\hline $\mathrm{Ni}-\mathrm{Fe}(1: 1)$ alloy & 13.7 & 9 & - \\
\hline $\mathrm{Ni}-\mathrm{Fe}(9: 1)$ alloy & $12 \sim 13$ & - & poor \\
\hline 300-Series stainless steel & $18 \sim 20$ & 2 & very good \\
\hline 400-Series stainless steel & $10 \sim 20$ & 2 & \\
\hline Electrolyte (GDC, YSZ, LSGM) & $10 \sim 20$ & & \\
\hline
\end{tabular}
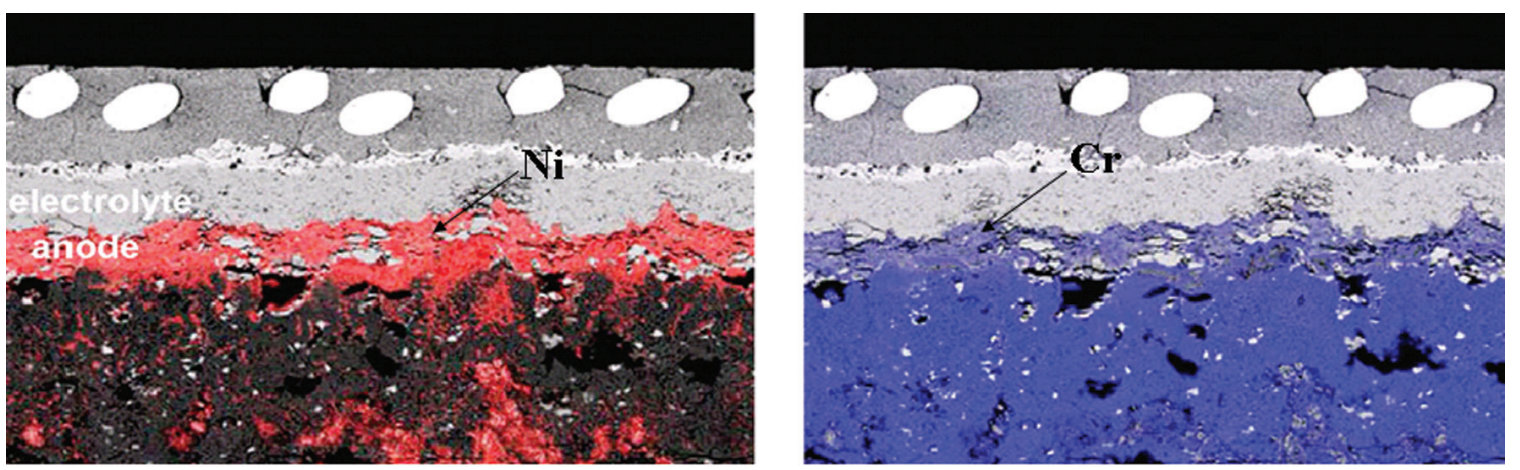

Fig. 6. SEM-EDX image of cross-scetion of metal-supported cell produced by plasma spray processing. Reproduced from Tucker et al. J. Power Sources 2010;195;4570-82 with permission of Elsevier [44].

을 금속 지지체는 좁은 범위의 작동 온도에서만 사용할 수 있다. 높은 전기화학적 성능과 탄화수소의 빠른 내 부 개질이 가능하면서 스테인리스강을 오랜 시간 사용 하기 위해서는 $625 \sim 650^{\circ} \mathrm{C}$ 이상의 높은 온도 범위에서 사용하여야 한다. 페라이트계 스테인리스강에 지속적이 고 보호적인 $\mathrm{Cr}_{2} \mathrm{O}_{3}$ 산화막을 형성하는 것은 금속 기반형 고체산화물 연료전지의 수명에 매우 중요하다. 다른 응 용 분야에서는 큰 문제로 고려되지 않지만, 고체산화물 연료전지에서 스테인리스강 지지체는 단순히 구성 요소 를 지지하는 역할 뿐만 아니라, 전극에서 발생한 전기화 학 반응의 산물인 전류를 수집하는 집전체 역할도 수행 하기 때문이다. 크로미아는 실리카나 알루미나와 같은 다른 보호 산화막과 비교해 전기 전도성이 높지만 고체 산화물 연료전지의 전체 전기 경로에서 가장 전도성이 낮은 물질이다. 그래서 두꺼운 크로미아 비늘이 형성되 면 저항이 매우 증가할 것으로 예상된다. Kofstad의 연 구에 따르면 $700^{\circ} \mathrm{C}$ 에서 벌크 $\mathrm{Cr}_{2} \mathrm{O}_{3}$ 의 전도도를 사용하
여 예상할 때, 산화막의 두께가 $1 \mu \mathrm{m}$ 변화함에 따라 면 적비저항 (Area Specific Resistance, ASR)은 대략 10 $\mathrm{mOhm} \cdot \mathrm{cm}^{-2}$ 증가가 예상된다고 보고하였다. ${ }^{[43]}$ 그러 나 $\mathrm{Cr}_{2} \mathrm{O}_{3}$ 산화막의 전기 전도성에 대한 영향은 이렇게 단순한 수치적 예측으로 판단할 수 없으며, 산소분압, 습도 조건, 산소 결손, 미세 공극의 존재 유-무 등 다 양한 요소에 의하여 결정된다. 그래서 사용 가능한 상한 작동 온도는 산화물 성장 속도와 원하는 고체산화물 연 료전지 수명에 의해 결정된다.

현재 페라이트계 스테인리스강을 지지체로 사용하여 제조된 고체산화물 연료전지는 양극, 음극 및 전해질을 스테인리스 스틸 기판에 다양한 방법으로 성장시켜 제 작된다. 이러한 종류의 고체산화물 연료전지는 스테인 리스강이 촉매적 특성이 없으므로 음극층을 준비해야 하는데, Franco 등은 Fig. 6과 같이 스테인리스강 기판 과 음극층 사이에 $\mathrm{Ni}$ 와 $\mathrm{Cr}$ 의 상호 확산이 발생하는 것을 확인하였다. ${ }^{[4]]}$ 금속 기판에서 음극층으로 확산된 $\mathrm{Cr}$ 이 
온은 양극층에서 $\mathrm{Cr}_{2} \mathrm{O}_{3}, \mathrm{NiCr}_{2} \mathrm{O}_{4}, \mathrm{FeO}$ 등으로 구성된 일부 절연 산화층을 형성하며, 확산된 $\mathrm{Ni}$ 이온은 산화환원 내성을 저하시키고 금속 기판의 열팽창 계수를 변 화시킵다.

\section{3. 결론}

고체산화물 연료전지는 높은 에너지 변환 효율과 연 료의 다양성으로 차세대 에너지 변환 시스템으로 많은 주목을 받고 있으나, 고체산화물 연료전지의 모든 구성 품이 금속산화물 및 세라믹 재료로 만들어져 낮은 기계 적 강도, 열충격에 대한 강도, 산화-환원 사이클 및 온 도 사이클에 대한 내구성 등을 문제점을 가지고 있다. 이러한 문제를 해결하고자 금속 지지체를 사용하여 기 존 고체산화물 연료전지의 단점을 보완하며 금속 지지 체의 낮은 단가로 인하여 생산 단가 또한 낮출 수 있다 는 장점이 있다. 현재 연구되고 있는 금속 지지체는 기 존 고체산화물 연료전지의 음극 소재에 사용되는 $\mathrm{Ni}$ 을 기반으로 하는 $\mathrm{Ni}$ 기반 금속 지지체와 $\mathrm{Fe}$ 을 기반으로 하 는 스테인리스강이 사용되고 있다. 이러한 금속 지지체 를 사용함으로서 온도 사이클에 대한 안정성 및 고온 환 원 분위기에서 기계적, 화학적, 장기적 내구성이 향상되 었다는 보고가 되었다. $\mathrm{Ni}$ 기반 금속 지지체는 열 팽창 계수가 고체산화물 연료전지에 비해 상대적으로 크다 는 단점으로 인하여 온도 사이클에 대한 안정성이 검증 되지 않았으며, 페라이트계 스테인리스강은 스테인리스 강 내부에 존재하는 금속 이온들의 산화에 의한 산화층 형성으로 고체산화물 연료전지의 내부 저항이 증가하고 금속 지지체와 음극 사이에 금속 양이온 확산으로 인하 여 장기 안정성에 문제가 있음이 보고되었다. 이러한 문 제들이 해결된다면 산화-환원 사이클, 온도 사이클에 서의 내구성 및 낮은 전압 전하율을 금속 지지체를 통해 구현하여 고체산화물 연료전지의 상업화가 가능해질 것 으로 기대된다.
1. C. K. Dyer, "Replacing the battery in portable electronics," Sci. American., 281 [1] 88-93 (1999).

2. C. Song, "Fuel processing for low-temperature and high-temperature fuel cells: Challenges, and opportunities for sustainable development in the 21st century," Catalysis today., 77 [1-2] 17-49 (2002).

3. A. B. Stambouli and E. Traversa, "Solid oxide fuel cells (SOFCs): a review of an environmentally clean and efficient source of energy," Renewable and Sustainable Energy Reviews, 6 [5] 433-455 (2002).

4. N. Q. Minh, "Ceramic fuel cells," J. Am. Ceramics Soc., 76 [3] 563-588 (1993).

5. T. 1shihara, H. Matsuda and Y. Takita, "Doped $\mathrm{LaGaO}_{3}$ perovskite type oxide as a new oxide ionic conductor," J. Am. Chem. Soc., 116 [9] 3801-3803 (1994).

6. T. Tsai, E. Perry and S. Barnett, "Low-temperature solid-oxide fuel cells utilizing thin bilayer electrolytes,"144 [5] L130 (1997).

7. T. Ishihara, K. Shimose and T. Kudo, H. Nishiguchi, T. Akbay, and Y. Takita, "Preparation of Yttria-Stabilized Zirconia Thin Films on Strontium-Doped $\mathrm{LaMnO}_{3}$ Cathode Substrates via Electrophoretic Deposition for Solid Oxide Fuel Cells," J. Am. Ceram. Soc., 83 [8] 1921-1927 (2000).

8. S. D. Kim, S. H. Hyun and J. Moon, J. H. Kim, R. H. Song, "Fabrication and characterization of anodesupported electrolyte thin films for intermediate temperature solid oxide fuel cells," J.Power Sources., 139 [1-2] 67-72 (2005).

9. J. W. Kim, A. V. Virkar, K. Z. Fung, K. Mehta and S. C. Singhal, "Low Temperature High Performance Anode Supported Solid Oxide Fuel Cells," J. Electrochem. Soc., 146 [1] 69-78 (1999).

10. T. Ishihara, H. Matsuda and Y. Takita, "Ishihara, Tatsumi, Hideaki Matsuda, and Yusaku Takita. "Effects of rare earth cations doped for La site on the oxide ionic conductivity of $\mathrm{LaGaO}_{3}$-based perovskite type oxide," Solid State Ionics., 79 147-151 (1995).

11. J. W. Yan, H. Matsumoto, M. Enoki and T. Ishihara, "High-Power SOFC Using $\mathrm{La}_{0.9} \mathrm{Sr}_{0.1} \mathrm{Ga}_{0.8} \mathrm{Mg}_{0.2} \mathrm{O}_{3-8}$ ' $\mathrm{Ce}_{0.8} \mathrm{Sm}_{0.2} \mathrm{O}_{2-\delta}$ Composite Film.” Electrochem. SolidState Lett., 8 [8] A389 (2005).

12. O. Yamamoto, Y. Takeda, R. Kanno and M. Noda, "Perovskite-type oxides as oxygen electrodes for high temperature oxide fuel cells," Solid State Ionics., 22 [2-3] 241-246 (1987). 
13. S. J. Skinner, "Recent advances in Perovskite-type materials for solid oxide fuel cell cathodes," Int. J. Inorg. Mater., 3 [2] 113-121 (2001).

14. Z. P. Shao and S. M. Haile, J. Ahn, P. D. Ronney, Z. Zhan and S. A. Barnett, "A thermally self-sustained micro solid-oxide fuel-cell stack with high power density," Nature., 435 [7043] 795-798 (2005).

15. A. A. Yaremchenko, A. L. Shaula, V. V. Kharton, J. C. Waerenborgh, D. P. Rojas, M. V. Patrakeev and F. M. B. Marques, "Ionic and electronic conductivity of $\mathrm{La}_{9.83-\mathrm{x}} \mathrm{Pr}_{\mathrm{x}} \mathrm{Si}_{4.5} \mathrm{Fe}_{1.5} \mathrm{O}_{26 \leftarrow \delta}$ apatites," Solid State Ionics., 171 [1-2] 51-59 (2004).

16. J. B. Goodenough and Y. H. Huang, "Alternative anode materials for solid oxide fuel cells," J. Power Source., 173 [1] 1-10 (2007).

17. M. Mogensen and S. Skaarup, "Kinetic and geometric aspects of solid oxide fuel cell electrodes." Solid State Ionics., 86-88 1151-1160 (1996).

18. S. P. Jiang, J. P. Zhang and K. Foger, "Deposition of chromium species at $\mathrm{Sr}$-doped $\mathrm{LaMnO}_{3}$ electrodes in solid oxide fuel cells: III. Effect of air flow," J. Electrochem. Soc., 148 [7] C447 (2001).

19. K. R. Williams and J. G. Smith,"Fuel Cell with SolidStateElectrolytes," 464,861 (1969).

20. A. Momma, Y. Kaga, T. Okuo, "Improvement of the Electrode Performance of Alloy Substrate-type Tubular SOFC,"Bulletin of the Electrotechnical Laboratory., 63 [3] 103-113 (1999).

21. A. Mineshige, K. Fukushima, S. Okada, T. Kikuchi, M. Kobune, T. Yazawa, K. Kikuchi, M. Inaba, Z. Ogumi, "Porous metal tubular support for solid oxide fuel cell design," Electrochem. Solid-State Lett., 9 [9] A427 (2006).

22. C. Hwang, C.-H. Tsai, C.-H. Lo, C.-H. Sun, "Plasma sprayed metal supported YSZ/Ni-LSGM-LSCF ITSOFC with nanostructured anode," J. Power Sources., 180 [1] 132-142 (2008).

23. H. J. Cho, G. M. Choi, "Fabrication and characterization of Ni-supported solid oxide fuel cell," Solid State Ionics., 180 [11-13] $792-795$ (2009).

24. T. Ishihara, J. Yan, M. Shinagawa, H. Matsumoto, "Ni-Fe bimetallic anode as an active anode for intermediate temperature SOFC using $\mathrm{LaGaO}_{3}$ based electrolyte film," Electrochim. Acta., 52 [4] 16451650 (2006).

25. T. Ishihara, J. W. Yan, M. Enoki, S. Okada, H.
Matsumoto, "Ni-Fe alloy-supported intermediate temperature SOFCs using $\mathrm{LaGaO}_{3}$ electrolyte film for quick startup," J. Fuel Cell Sci. Technol., 5 [3] 031205-1-031205-3 (2008).

26. Y.W. Ju, H. Eto, T. Inagaki, T. Ishihara, "High power SOFC using LSGM film on NiFe porous bi-metal substrate," ECS Trans., 25 [2] 719 (2009).

27. J. Yan, M. Enoki, H. Matsumoto, T. Ishihara, "Nanoporous Ni-Fe bimetallic plates for nonfragile, reliable SOFCs," Electrochem. Solid-State Lett., 10 [9] B139 (2007).

28. Y. Lee, G.M. Choi, "Ceria Film Supported on Ni-Fe Metal Film," ECS Trans., 25 [2] 727 (2009).

29. H.C. Park, A.V. Virkar, "Bimetallic (Ni-Fe) anodesupported solid oxide fuel cells with gadolinia-doped ceria electrolyte," J. Power Sources., 186 [1] 133-137 (2009).

30. J.H. Zhu, S.J. Geng, Z.G. Lu, W.D. Porter, "Evaluation of binary $\mathrm{Fe}-\mathrm{Ni}$ alloys as intermediatetemperature SOFC interconnect," J. Electrochem. Soc., 154 [12] B1288 (2007).

31. S. Molin, M. Gazda, B. Kusz, P. Jasinski, "Evaluation of $316 \mathrm{~L}$ porous stainless steel for SOFC support," J. Eur. Ceram. Soc., 29 [4] 757-762 (2009).

32. P. Bance, N.P. Brandon, B. Girvan, P. Holbeche, S. O'Dea, B.C.H. Steele, "Spinning-out a fuel cell company from a UK University - 2 years of progress at Ceres Power," J. Power Sources., 131 [1-2] 86-90 (2004).

33. N.P. Brandon, A. Blake, D. Corcoran, D. Cumming, A. Duckett, K. El-Koury, D. Haigh, C. Kidd, R. Leah, G. Lewis, C. Matthews, N. Maynard, N. Oishi, T. McColm, R. Trezona, A. Selcuk, M. Schmidt, L. Verdugo, "Development of metal supported solid oxide fuel cells for operation at 500-600 ${ }^{\circ} \mathrm{C}$," J. Fuel Cell Sci. Technol., 1 [1] 61-65 (2004).

34. N. Oishi, Y. Yoo, "Fabrication of cerium oxide based SOFC having a porous stainless steel support," ECS Trans., 25 [2] 739 (2009).

35. P. Blennow, J. Hjelm, T. Klemensø, Å. Persson, K. Brodersen, A.K. Srivastava, H.L. Frandsen, M. Lundberg, S. Ramousse, M. Mogensen, "Development of planar metal supported SOFC with novel Cermet anode," ECS Trans., 25 [2] 701-710 (2009).

36. I. Villarreal, C. Jacobson, A. Leming, Y. Matus, S. 
Visco, L. DeJonghe, "Metal-supported solid oxide fuel cells," Electrochem. Solid State Lett., 6 [9] A178 (2003).

37. M.C. Tucker, G.Y. Lau, C.P. Jacobson, L.C. DeJonghe, S.J. Visco, "Stability and robustness of metal-supported SOFCs," J. Power Sources., 175 [1] 447-451 (2008).

38. R.T. Leah, N.P. Brandon, P. Aguiar, "Modelling of cells, stacks and systems based around metalsupported planar IT-SOFC cells with CGO electrolytes operating at $500-600{ }^{\circ} \mathrm{C}, " \mathrm{~J}$. Power Sources., 145 [2] 336-352 (2005).

39. R. Hui, D. Yang, Z. Wang, S. Yick, C. Decès-Petit, W. Qua, A. Tuck, R. Maric, D. Ghosh, "Metal-supported solid oxide fuel cell operated at $400-600^{\circ} \mathrm{C}$," J. Power Sources., 167 [2] 336-339 (2007).

40. Q.-A. Huang, B. Wang, W. Qu, H. Rob, "Impedance diagnosis of metal-supported SOFCs with SDC as electrolyte," J. Power Sources., 191 [2] 297-303 (2009).

41. D. Waldbillig, O. Kesler, "Characterization of metalsupported axial injection plasma sprayed solid oxide fuel cells with aqueous suspension plasma sprayed electrolyte layers," J. Power Sources., 191 [2] 320329 (2009).

42. H. Kurokawa, G.Y. Lau, C.P. Jacobson, L.C. De Jonghe, S.J. Visco, "Water-based binder system for SOFC porous steel substrates," J. Mater. Processing Technol., 182 [1-3] 469-476 (2007).

43. A. Holt, P. Kofstad, "Electrical conductivity and defect structure of $\mathrm{Cr}_{2} \mathrm{O}_{3}$. II. Reduced temperatures (< 1000 C)," Solid State Ionics., 69 [2] 137-143 (1994).

44. M. C. Tucker, "Progress in metal-supported solid oxide fuel cells: A review," J. Power Sources., 195 [15] 4570-82 (2010).

\section{ㅇㅈㅜㅜ 용 완

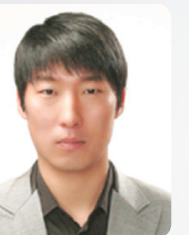 \\ ( 2011년 일본 큐슈대학교 응용화학공학과 박사 \\ ( 2011년 일본 큐슈대학교 응용화학공학과 연구교수 \\ - 2014년 울산과학기술원 에너지화학공학과 연구교수 \\ - 2016년 원광대학교 화학융합공학과 조교수 \\ ○ 2020년 원광대학교 화학융합공학과 부교수}

